\title{
1.75
}

The Pliocene Conant Creek Tuff in the northern part of the

Teton Range and Jackson Hole, Wyoming

GEOLOG I A A S S R V EY B ULLET IN $1435-$ C

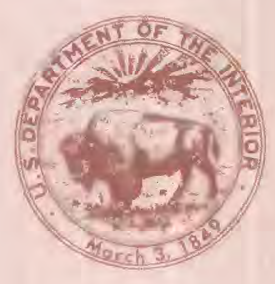





\section{The Pliocene Conant Creek Tuff in the northern part of the \\ Teton Range and Jackson Hole, Wyoming}

By Robert L. Christiansen and J. D. Love

CONTRIBUTIONS TO STRATIGRAPHY

GE OLOG I A L S UR VEY B ULLETIN $1435-\mathrm{C}$

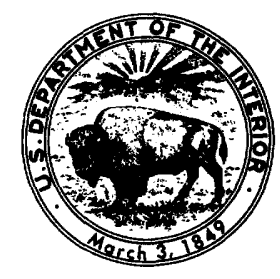




\section{UNITED STATES DEPARTMENT OF THE INTERIOR}

CECIL D. ANDRUS, Secretary

\section{GEOLOGICAL SURVEY}

V. E. McKelvey, Director

Library of Congress Cataloging in Publication Data

Christiansen, Robert L.

The Pliocene Conant Creek Tuff in the northern part of the Teton Range and Jackson Hole, Wyoming.

(Geologica1 Survey Bulletin 1435-C)

Bibliography: p. 8-9.

1. Geology, Stratigraphic--Pliocene. 2. Volcanic ash, tuff, etc.-Wyoming-Teton Co.

3. Geology Wyoming-Teton Co. I. Love, John David, 1913- , joint author.

II. Title. III. Series: United States Geological Survey Bulletin 1435-C.

QE75.B9 no. 1435-C [QE695] 557.3'08s [552'.2] 77-10417

For sale by the Superintendent of Documents, U. S. Government Printing Office Washington, D. C. 20402

S tock Number 024-001-03033-1 


\section{CONTENTS}

$\begin{array}{lr}\text { Abstract } & \text { Page } \\ \text { Introduction } & \text { C1 } \\ \text { Name and definition } & \\ \text { Distribution and thickness } & \\ \text { Lithology } & \\ \quad \text { Type section } & \text { Reference section } \\ \text { Stratigraphic and structural relations } & \\ \text { Age and correlation } & \\ \text { References cited } & \end{array}$

\section{ILLUSTRATIONS}

Figure 1. Index map showing localities referred to in text and relation of Teton Range to Yellowstone National Park

2. Geologic map showing outcrop area of the Conant Creek Tuff

3. Map showing recognized occurrences of Conant Creek Tuff in the Teton Range-Jackson Hole area 



\title{
THE PLIOGENE CONANT GREEK TUFF IN THE NORTHERN PART OF THE TETON RANGE AND JACKSON HOLE, WYOMING
}

\author{
By Robert L. Christiansen and J.D. Love
}

\section{ABSTRACT}

The Conant Creek Tuff comprises a widespread sheet of rhyolitic ash-flow tuff, mainly welded, and minor associated bedded tuff. It is poor in phenocrysts but commonly has abundant lithophysae. The Conant Creek Tuff is exposed on both sides of the Teton Range and nearby areas of northwestern Wyoming and in northeastern Idaho, and it probably also occurs elsewhere in eastern Idaho near the Snake River Plain, and in southwestern Montana. The Conant Creek Tuff is about 5.8 m.y. old. It underlies the lower Pleistocene Huckleberry Ridge Tuff and forms a potentially useful stratigraphic marker of Pliocene age.

\section{INTRODUCTION}

We have mapped a heretofore unnamed and undescribed rhyolitic welded ash-flow tuff at the north end and along both the east and the west sides of the Teton Range in northwestern Wyoming. This tuff overlies the Teewinot Formation and most of the Pliocene Bivouac Formation, which overlies the Teewinot (Love, 1956); the tuff underlies the Pleistocene Huckleberry Ridge Tuff (Christiansen and Blank, 1972). The newly described unit is sufficiently distinctive and widespread to warrant a formal stratigraphic name. Figure 1 shows the study area and its relations to the Teton Range and to Yellowstone National Park.

\section{NAME AND DEFINITION}

We adopt the name Conant Creek Tuff for this newly mapped sequence. The name is taken from Conant Creek (fig. 2), in the vicinity of which the tuff is widely exposed.

Exposures within the area of figure 2 are not adequate to show a single complete and well-exposed section. Therefore, two sections are described. Section A (fig. 2), in sec. 5, T. 47 N., R. 117 W, Grassy Lake Reservoir 15-minute quadrangle, Teton County, Wyoming, is designated the type section, and section $B$ is designated a reference section. These sections are described in the section entitled "Lithology." 


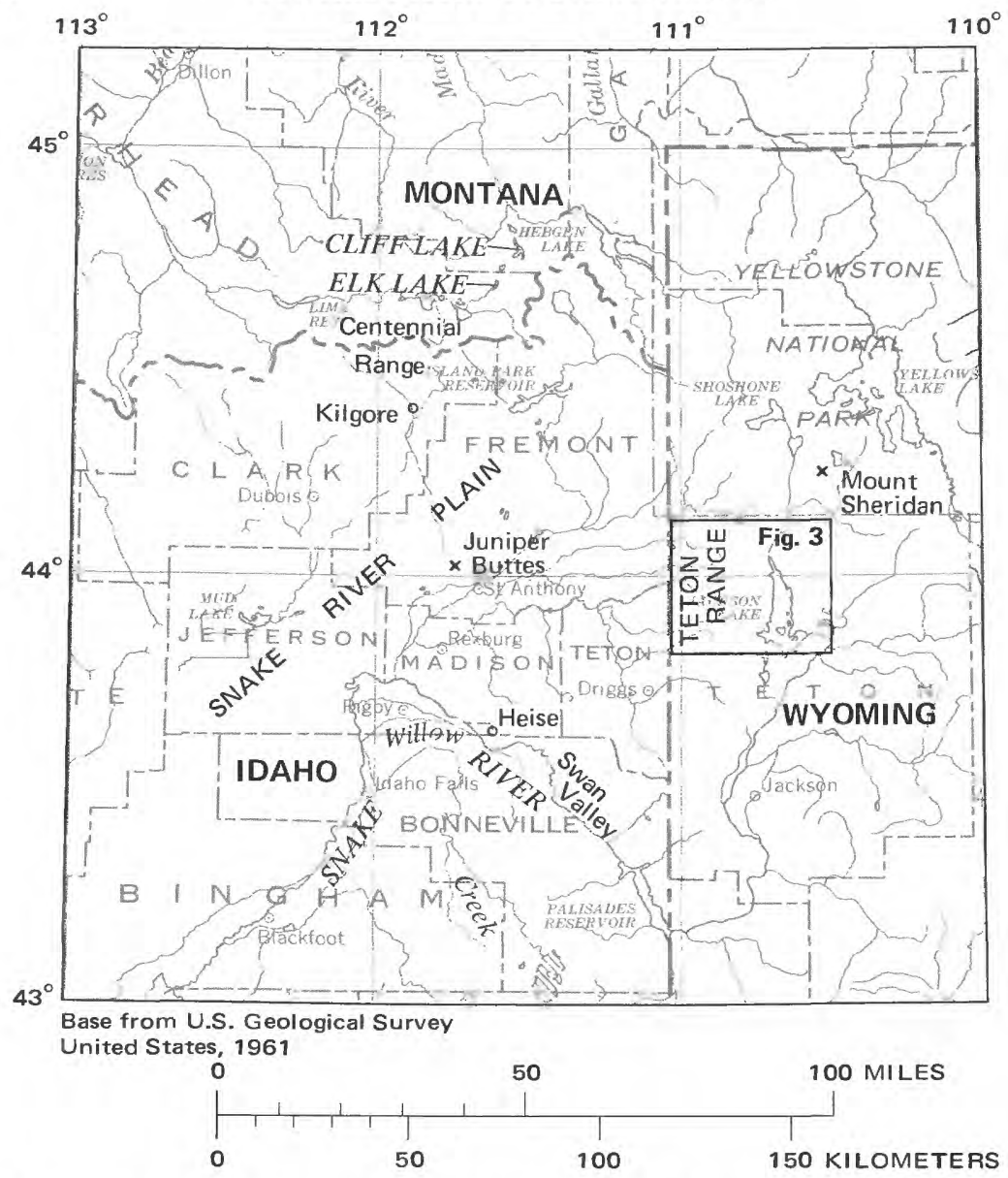

FIGURE 1.-Index map showing some localities referred to in text, and relation of the Teton Range to Yellowstone National Park and adjacent geographic and geologic features.

\section{DISTRIBUTION AND THICKNESS}

In addition to the area shown in figure 2 , the Conant Creek Tuff is exposed sporadically along both sides of the Teton Range (fig. 3). The

Figure 2.-Geologic map showing outcrop area of the Conant Creek Tuff (Tcc, stippled) in the vicinity of sections A and B. Other geologic units: sr, sedimentary rocks of pre-Eocene age; Th, Hominy Peak Formation (Eocene); Qyh, Huckleberry Ridge Tuff of the Yellowstone Group (Pleistocene); Qfr, Falls River Basalt (Pleistocene); Qg, glacial deposits (Pleistocene); Qt, talus and landslide deposits (Pleistocene and Holocene); and Qa, alluvium and swamp deposits (Pleistocene and Holocene). Location of figure 2 indicated in figure 3. Geology from Christiansen, Blank, Love, and Reed (1977). 
Conant Creek is present in the northern Tetons just northeast of Survey Peak (locality C, fig. 3), and small outcrops are present near the head of Glade Creek (locality D, fig. 3) and along Polecat Creek (locality E, fig. 3). Farther south, in Jackson Hole, somewhat larger

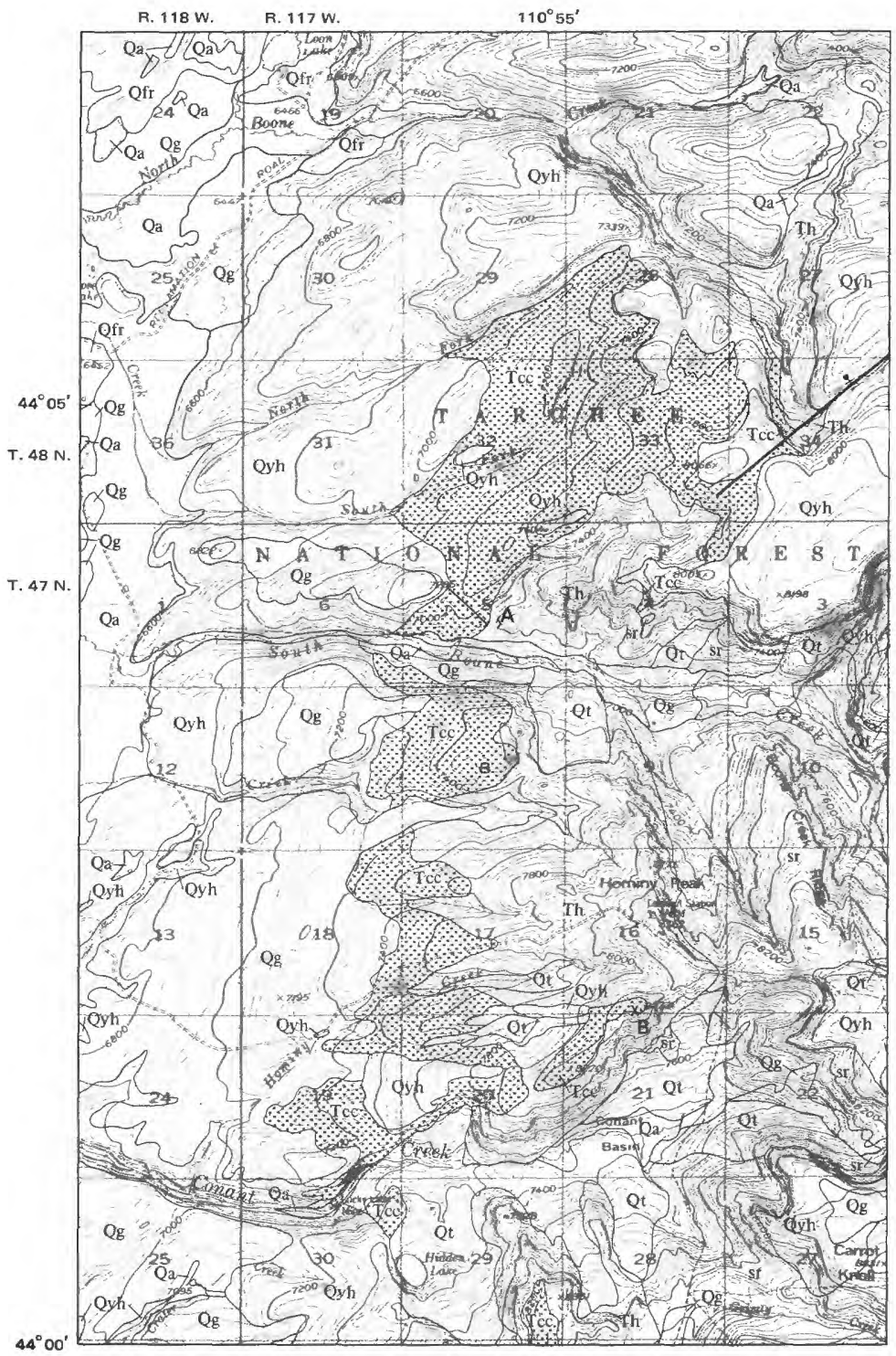

Base from U.S. Geological Survey

1:62,500 Grassy Lake Reservoir, 1956

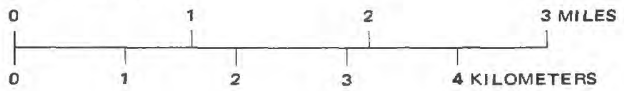




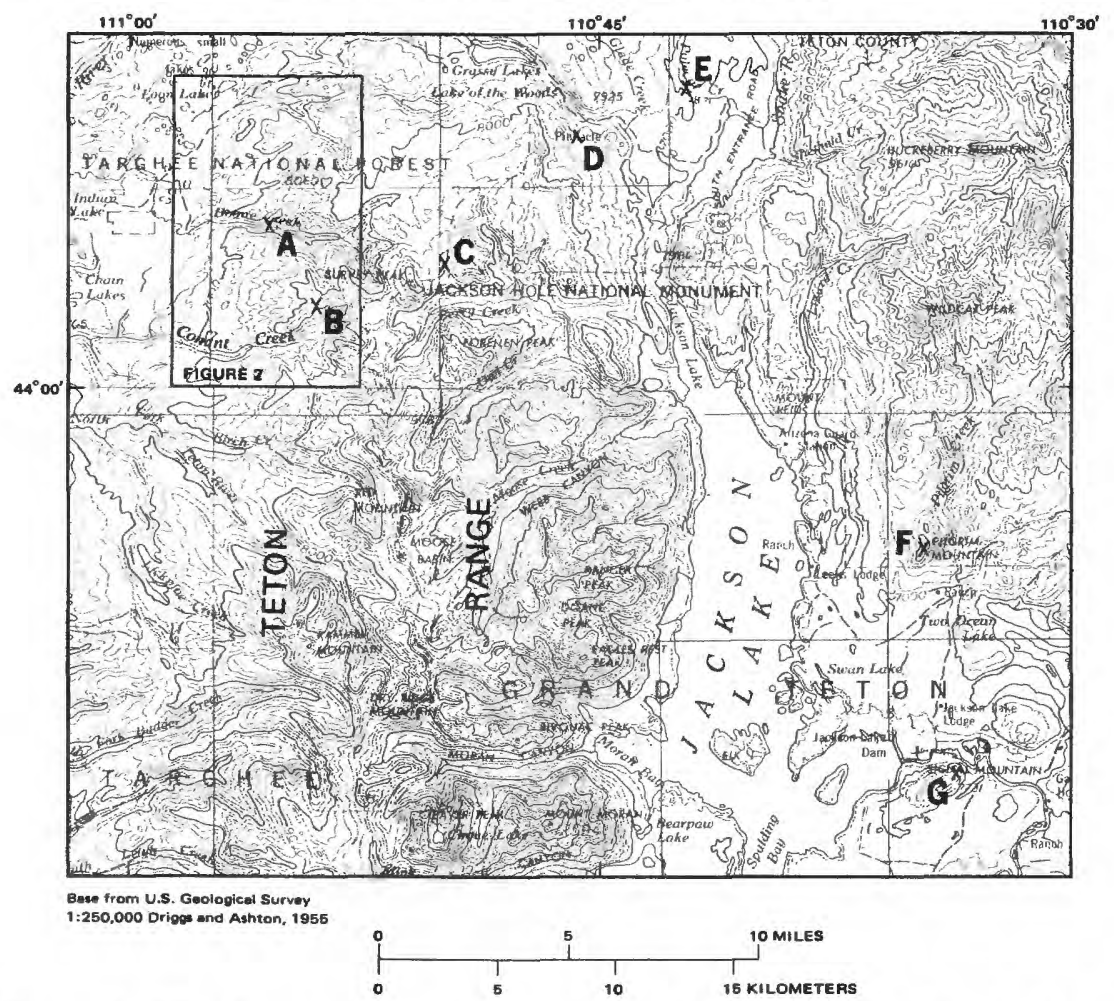

Figure 3.-Map showing recognized occurrences of Conant Creek Tuff in the Teton

Range-Jackson Hole area. Lettered localities are referred to in text. Location of figure 3 indicated in figure 1.

but faulted outcrops of the Conant Creek Tuff are present on and near Pilgrim Mountain (locality F, fig. 3; Love, 1973) and the northeast spur of Signal Mountain (locality G, fig. 3).

Along the west side of the Teton Range, the Conant Creek Tuff has been identified as far south as the head of the basin of Hidden Lake, just south of the area of figure 2.

Welded tuffs lithologically like the Conant Creek Tuff also underlie the Huckleberry Ridge Tuff of the Yellowstone Group on and near the Snake River Plain in eastern Idaho (fig. 1). Exposures of these tuffs, at least some of which probably are the Conant Creek, are present on the south side of the Snake River in the Swan Valley-Willow Creek area; near Heise (H. J. Prostka, written commun., 1974); on the Juniper Buttes, about $15 \mathrm{~km}$ northwest of St. Anthony; and in the Centennial Range, north of Kilgore. Probable Conant Creek Tuff also is present beneath the Huckleberry Ridge Tuff in the Elk Lake and Cliff Lake areas of southwestern Montana.

The Conant Creek Tuff at its type section near South Boone Creek 
is about $125 \mathrm{~m}$ thick, the maximum thickness known. Elsewhere it ranges in thickness from near 0 to more than $100 \mathrm{~m}$.

The eruptive source of the Conant Creek Tuff is not known with certainty but is somewhere in the eastern Snake River Plain. Reconnaissance observations suggest that the source may have been a now largely buried resurgent caldera centered at the Juniper Buttes (fig. 1).

\section{LITHOLOGY}

The Conant Creek Tuff is rhyolitic, mainly welded, gray to purplish gray where fresh, and generally has only sparse phenocrysts. Spherical lithophysal cavities are abundant in many places. Lithologically, the unit resembles phenocryst-poor part of the overlying Huckleberry Ridge and Lava Creek Tuffs. A layer grading from porous gray glass to black obsidian generally is present near the base.

\section{TYPE SECTION}

The type section (locality A, fig. 2) was measured on the north side of South Boone Creek where a steep-sided tributary enters the main creek in the NE1/4SW1/4 sec. 5, T. 47 N., R. 117 W., Grassy Lake Reservoir 15-minute quadrangle, Teton County, Wyoming. The section was masured by J. D. Love, using steel tape and compass, August 24, 1972, and is supplemented by lithologic descriptions by R. L. Christiansen, July 19, 1970.

\section{Unit and description}

Member A, Huckleberry Ridge Tuff:

Ash-flow tuff, medium-gray, brown-weathering, densely welded; contains abundant large phenocrysts of quartz, sanidine, and plagioclase; basal few meters poorly exposed.

Unconformity on a surface of considerable relief. There is probably a slight angular discordance, but the amount is difficult to determine.

3. Ash-flow tuff, pale-purplish-gray to grayish-brown, moderately to densely welded, devitrified; platy-weathering; contains abundant spherical 1-3-cm lithophysae in lower part; sparse small phenocrysts are mainly quartz, sanidine, and plagioclase

2. Ash-flow tuff, black densely welded obsidian; breaks into conspicuous columns that have straight to curved grooves parallel to the long axes of the columns; contains sparse small phenocrysts mainly of quartz, sanidine, and plagioclase; welded shards visible megascopically on fresh surfaces

1. Ash-flow tuff, pale-purplish-pink, nonwelded to incipiently
Approximate

feet $\quad$ thickness

122.0 


\section{Type section-Continued}

Unit and description

1. Ash-flow tuff, etc.-Continued

welded glassy, friable; contains slightly more abundant small phenocrysts, mainly of quartz, sanidine, and plagioclase, than units 2 and 3 . About $100 \mathrm{~m}$ southeast, across a major ravine, unit 1 consists of soft loose black to grayish-orange glass shards.

Thickness of unit at both sites is about the same -..-

Total thickness of Conant Creek Tuff

$5-6 \quad 1.53-\quad 1.83$

$407-8 \quad 124.14-124.44$ Thickness
feet meters

Angular unconformity of about $10^{\circ}-15^{\circ}$. The precise amount of relief on the surface of unconformity cannot be determined because of poor exposures.

Hominy Peak Formation:

Volcanic breccia and conglomerate, red, brown, and gray; dark in outcrop; consists of angular to subrounded fragments of red, pink, brown, gray, or green pyroxene andesite and basalt.

\section{REFERENCE SECTION}

A reference section (locality $\mathrm{B}$, fig. 2) was measured on the south face of hill 8373 in the SE $1 / 4 \mathrm{SW}^{1 / 4}$ sec. 16, T. 47 N., R. 117 W., Grassy Lake Reservoir quadrangle, Teton County, Wyoming. The section was measured by J. D. Love, using steel tape and compass, August 15, 1976, and by R. L. Christiansen, using a Jacob-staff level, September 27, 1973.

\section{Unit and description}

Member B, Huckleberry Ridge Tuff:

Ash-flow tuff, medium-gray to brownish-gray, partially welded, devitrified and vapor-phase zones.

Unconformity on a surface of low relief; Huckleberry Ridge Tuff onlaps the more steeply dipping Conant Creek Tuff, and contact is exposed poorly about $450 \mathrm{~m}$ west of the top of the measured section of Conant Creek Tuff.

Conant Creek Tuff:

3B. Ash-flow tuff, grayish-brown, partially welded, vapor phase zone; flaggy-splitting, slope-forming, poorly exposed; contains sparse phenocrysts less than $1 \mathrm{~mm}$ mainly of quartz, sanidine, and plagioclase; basal contact gradational

3A. Ash-flow tuff, brown to pinkish-gray, densely welded, devitrified; blocky-weathering, ledge-forming; contains abundant $2-5 \mathrm{~cm}$ spherical to radial-gash cavities lined with lithophysal crystals; sparse phenocrysts less than 1 mm mainly of quartz, sanidine, and plagioclase; basal contact gradational within a few centimeters

2B. Ash-flow tuff, dark- to medium-gray, densely welded spherulitic; breaks into tough, hard blocks, ledgeforming; spherulites generally $1-5 \mathrm{~mm}$, locally separated

\section{Thickness \\ feet meters}

$4.9 \quad 1.50$

$9.0 \quad 2.75$ 


\section{Reference section-Continued}

\section{Unit and description}

2B. Ash-flow tuff, etc.-Continued by small patches of black obsidian; contains sparse phenocrysts less than $1 \mathrm{~mm}$, mainly of quartz, sanidine, and plagioclase; basal contact sharp

2A. Ash-flow tuff, black, densely welded obsidian; breaks into conspicuous vertical columns, and into conchoidally fractured blocks as much as $60 \mathrm{~cm}$ in diameter, forms broken ledge; contains sparse phenocrysts less than 1 $\mathrm{mm}$, mainly of quartz, sanidine, and plagioclase; welded shards visible megascopically on fresh surfaces; basal contact sharp to gradational over only a few centimeters

1B. Ash-flow tuff, orange-pink, incipiently welded, glassy friable, poorly exposed; contains sparse phenocrysts mainly of quartz, sanidine, and plagioclase; basal contact gradational over several centimeters

1A. Ash-flow tuff, white, nonwelded, glassy, crudely sorted but not obviously bedded, friable, porous, coarse-grained; consists of angular, curved and wishbone-shaped clear shards and sparse chunks of fibrous pumice less than 1 $\mathrm{cm}$ in a clayey matrix of weathered volcanic dust; contains sparse granules of obsidian, and phenocrysts less than $1 \mathrm{~mm}$ mainly of quartz, sanidine, and plagioclase; phenocrysts slightly more abundant than in units 2 and 3

Total thickness of Conant Creek Tuff

Angular unconformity. Conant Creek Tuff has a regional strike of approximately N. $15^{\circ} \mathrm{E}$; regional dip varies between $6^{\circ}$ and $9^{\circ} \mathrm{W}$. Some of the variability may be the result of differential compaction because of deposition on a surface of slight relief. The underlying Hominy Peak Formation strikes N. $10^{\circ} \mathrm{E}$. and dips $20^{\circ}-25^{\circ} \mathrm{W}$.

Hominy Peak Formation

Volcanic breccia and conglomerate, dark-red-brown to green, crudely stratified; consists of angular to subrounded fragments of scoriaceous to massive pyroxene andesite interbedded with irregular olive to green coarse-grained tuff; upper part reddened parallel to the contact of the Conant Creek Tuff.

\section{STRATIGRAPHIC AND STRUCTURAL RELATIONS}

The lower and upper contacts of the Conant Creek Tuff in sections $\mathrm{A}$ and $\mathrm{B}$ have been described above. On the west side of the Teton Range, the Conant Creek Tuff everywhere lies on the Hominy Peak Formation (Love and others, 1977). Regional mapping shows that the Conant Creek Tuff was faulted and tilted slightly westward and that erosion created a moderate to rough topography on the Conant Creek before the Huckleberry Ridge Tuff was emplaced on it. The time lapse between emplacement of the two tuffs was marked by tilting and uplift of the Teton Range relative to Teton Valley on the west and Jackson Hole on the east. 


\section{AGE AND CORRELATION}

The Conant Creek Tuff is of Pliocene age. Obsidian from the base of the ash-flow tuff has been dated by the K-Ar method as $5.78 \pm 0.08$ m.y. (J. D. Obradovich, written commun., 1976) and by the fissiontrack method as $4.2 \pm 0.7$ m.y. (G. A. Izett, written commun., 1975). Its paleomagnetic polarity is reverse (R. L. Reynolds, oral commun., 1974). The overlying Huckleberry Ridge Tuff has a K-Ar age of 1.9 m.y. (Christiansen and Blank, 1972; J. D. Obradovich, written commun., 1974).

A previously reported K-Ar age of $2.5 \mathrm{~m} . \mathrm{y}$. from the northwest side of Signal Mountain in Jackson Hole (Love and Reed, 1968, p. 101) was obtained from sanidine of a water-laid tuff just below the basal ash flow of the Huckleberry Ridge Tuff. The Conant Creek Tuff does not crop out at this site, but $1,520 \mathrm{~m}$ farther east-southeast on Signal Mountain it probably underlies gravels in the Bivouac Formation (Love, 1956), which unconformably underlies the Huckleberry Ridge Tuff. The Conant Creek overlies about $200 \mathrm{~m}$ of gravel in the lower part of the type Bivouac Formation, which in turn is younger than Teewinot Formation (Love, 1956). The type Teewinot, about $30 \mathrm{~km}$ farther south in Jackson Hole, contains thick beds of rhyolitic tuff and some pebble beds of rhyolite, pumice, and obsidian; the Teewinot there was reported as middle Pliocene on the basis of vertebrate fossils (Love, 1956); it has a K-Ar age of $9.2 \mathrm{~m}$.y. (Evernden and others, 1964, p. 185-186). The Conant Creek Tuff now adds another dated unit to the upper Cenozoic stratigraphy of Jackson Hole.

The Heart Lake Conglomerate (Love and Keefer, 1969) on the south slopes of Mount Sheridan (fig. 1) in southern Yellowstone National Park $21 \mathrm{~km}$ northeast of locality E (fig. 3), contains abundant rhyolite and black obsidian roundstones in a tuff matrix. This formation has not been dated, but on the basis of lithology and regional considerations, it is considered by Love and Keefer to be of Pliocene or Pleistocene age. The clastic rhyolitic debris may have been derived by erosion from the Conant Creek Tuff.

\section{REFERENCES CITED}

Christiansen, R. L., and Blank, H. R., Jr., 1972, Volcanic stratigraphy of the Quaternary Rhyolite Plateau in Yellowstone National Park: U.S. Geol. Survey Prof. Paper 729-B, $18 \mathrm{p}$.

Christiansen, R. L., Blank, H. R., Jr., Love, J. D., and Reed, J. C., 1977, Geologic map of the Grassy Lake Reservoir quadrangle, Wyoming: U.S. Geol. Survey, Geol. Quad. Map GQ-1459 (in press).

Evernden, J. F., Savage, D. E., Curtis, G. H., and James G. T., 1964, Potassium-argon dates and the Cenozoic mammalian chronology of North America: Am. Jour. Science, v. 262, no. 2, p. 145-198. 
Love, J. D., 1956, New geologic formation names in Jackson Hole, Teton County, northwestern Wyoming: Am. Assoc. Petroleum Geologists Bull., v. 40, no. 8, p. $1899-1914$.

1973, Geologic map of the Two Ocean Lake quadrangle, Teton County, Wyoming: U.S. Geol. Survey open-file map, scale 1:24,000.

Love, J. D., and Keefer, W. R., 1969, Basin Creek uplift and Heart Lake Conglomerate, southern Yellowstone National Park, Wyoming, in Geological Survey research 1969: U.S. Geol. Survey Prof. Paper 650-D, p. D122-D130.

Love, J. D., Leopold, E. B., and Love, D. W., 1977, Eocene rocks, fossils, and geologic history, Teton Range, northwest Wyoming: U.S. Geol. Survey Prof. Paper 932-B (in press).

Love, J. D., and Reed, J. C., Jr., 1968, Creation of the Teton landscape-the geologic story of Grand Teton National Park: Grand Teton Natural History Assoc., 120 p. 



